\title{
SURGICAL TREATMENT OF DISTAL RADIUS FRACTURES WITH A VOLAR LOCKED PLATE: CORRELATION OF CLINICAL AND RADIOGRAPHIC RESULTS
}

Claudio Roberto Martins Xavierr', Danilo Canesin Dal Molin², Rafael Mota Marins dos Santos², Roberto Della Torre dos Santos ${ }^{3}$, Julio Cezar Ferreira Neto ${ }^{3}$

\begin{abstract}
Objectives: To analyze and correlate the clinical and radiographic results from patients with distal radius fractures who underwent surgical treatment with a fixed-angle volar locked plate. Methods: Sixty-four patients with distal radius fractures were evaluated. They all underwent surgical treatment with a volar locked plate for the distal radius, with a minimum of six months of postoperative followup. They underwent a physical examination that measured range of motion and grip strength, answered the Disabilities of the Arm, Shoulder, and Hand (DASH) questionnaire and underwent radiographic examination. Results: In the physical
\end{abstract}

examination on the patients, all the range-ofmotion measurements were reduced. Grip strength measured in kgf was on average $85.8 \%$ of the strength on the unaffected side. The mean DASH score was 15.99. A significant relationship was found between lower DASH scores and losses of extension and grip strength. On the radiographs, the mean values in relation to the unfractured side were $84.0 \%$ for radial inclination, $85.4 \%$ for radial length and $86.8 \%$ for volar deviation of the radius. Loss of radial length was correlated with losses of extension and grip strength.

Keywords - Radius Fractures; Bone Plates; Fracture Fixation; Range of Motion, Articular; Treatment Outcome

\section{INTRODUCTION}

Fractures of the distal radius are frequent injuries and account for 10 to $12 \%$ of the fractures of the human skeleton ${ }^{(1)}$. Most of them occur following low-energy trauma, such as falls from the individual's own height, and they have been correlated with losses of bone density (osteoporosis) ${ }^{(2,3)}$. In young patients, on the other hand, they are associated with high-energy trauma, such as in traffic accidents, sports accidents and falls from a height.

In the literature, there is no single treatment method that would be effective for all types of distal radius fracture ${ }^{(4,5)}$. Among the forms of treatment that have been described are plastercast immobilization, use of intrafocal, extrafocal or intramedullary percutaneous Kirschner wires, dorsal and volar plates and external fixation ${ }^{(6-9)}$.

Recent advances in implants and techniques, such as locked plates, have changes the orthopedic treatment of these fractures ${ }^{(8)}$.

Locked plate and screw systems act as a single unit for fracture fixation, unlike conventional plates, which require compression between the implant and the bone for stabilization. In elderly

1 - Head Physician of the Hand Surgery Group, "Francisco Morato de Oliveira” State of São Paulo Public Servants' Hospital (IAMSPE), São Paulo, SP, Brazil.

2 - Third-year Resident Physician, "Francisco Morato de Oliveira” State of São Paulo Public Servants' Hospital (IAMSPE), São Paulo, SP, Brazil.

3 - Attending Physician in the Hand Surgery Group, “Francisco Morato de Oliveira” State of São Paulo Public Servants’ Hospital (IAMSPE), São Paulo, SP, Brazil.

Work performed at the "Francisco Morato de Oliveira” State of São Paulo Public Servants' Hospital (IAMSPE), São Paulo, SP, Brazil.

Correspondence: Rua Borges Lagoa 1755, sala 180, $1^{\circ}$ andar, Vila Clementino, 04038-034 São Paulo, SP. E-mail: claudioxavier@uol.com.br

Work received for publication: October 29, 2010; accepted for publication: May 25, 2011.

The authors declare that there was no conflict of interest in conducting this work 
patients who have lower bone density, they provide greater rigidity and better stabilization than shown by conventional plates. Furthermore, the locked plate-screw mechanism functions as a substitute for the bone cortex, thus making it possible to use monocortical screws ${ }^{(10-13)}$.

Stable internal fixation has advantages, including early mobilization of the wrist and fingers, thus facilitating postoperative rehabilitation and diminishing the stiffness caused by prolonged immobilization $^{(14)}$.

Biomechanical studies have shown that fractures fixed using locked plates have greater stability than either dorsal or volar non-locked plates. Volar plates have the advantage of causing lower incidence of complications relating to the extensor tendons, compared with dorsal plates ${ }^{(9,12,14,15)}$.

The aim of surgical treatment for unstable fractures of the distal radius is to achieve anatomical reduction and enable the patient to have a better functional recovery ${ }^{(13,16)}$. However, studies have shown that there is no correlation between reestablishment of the volar tilt, radial length and radial tilt and subjective functional results, among patients treated with plaster-cast immobilization or Kirschner wires ${ }^{(17,18)}$.

The relationship between these radiographic measurements and recovery of range of motion is a matter of controversy. Radial length and volar angle are the factors most cited as responsible for repercussions on wrist movement, among patients treated for fractures of the distal radius ${ }^{(18-20)}$.

The aim of this study was to evaluate and correlate range of motion, palm grip strength and subjective functional limitations with radiographic indexes, among patients undergoing osteosynthesis to treat fractures of the distal radius, using a fixed-angle locked volar plate.

\section{METHODS}

A retrospective study was conducted to correlate objective and subjective clinical evaluations with radiographic results, among patients undergoing osteosynthesis of the distal extremity of the radius using a T-shaped fixed-angle locked plate of thickness
$2.4 \mathrm{~mm}$, by means of the volar route. These patients were operated between January 2006 and April 2009.

Over this period, 166 patients underwent this surgical procedure. Surgery was indicated in cases in which the fractures presented dorsal inclination of the distal fragment greater than $20^{\circ}$, radial shortening of $10 \mathrm{~mm}$ or over, joint incongruence and dorsal comminution, in conformity with the instability criteria proposed by Albertoni et al ${ }^{(21)}$, Cooney et $a l^{(22)}$ and Lafontaine et $a l^{(23)}$. Fractures that lost their reduction during nonsurgical treatment consisting of plaster-cast immobilization also underwent fixation.

The inclusion criteria for this study were that these patients with fractures had initially undergone an attempt at closed reduction under local anesthetic in the emergency service; they had undergone operations performed by the hand surgery group; had been followed up for a minimum of six months after the operation; were over 18 years of age; had signed the free and informed consent statement; had followed a postoperative rehabilitation protocol; and had not presented any previous functional deficit in the affected limb, or fractures of dislocations in their upper limbs, or exposed or bilateral fractures. Thus, out of the 166 patients who underwent operations, 64 satisfied the inclusion criteria and formed part of the study group.

The patients' ages ranged from 19 to 86 years, with a mean of 58.2 years, of whom $29(45.3 \%)$ were under the age of 60 years and $35(54.7 \%)$ were over the age of 60 years. Twenty patients $(31.2 \%)$ were male and 44 $(68.8 \%)$ were female. The dominant side was affected in 27 patients $(42.2 \%)$ and the non-dominant side in $37(57.8 \%)$. The trauma mechanisms were falls from the individuals' own height (33 cases; 51.6\%), traffic accidents (14 cases; $21.9 \%)$ and falls from a height (17 cases; $26.5 \%)$.

At the time of the evaluations on the patients, the mean time elapsed since the operation was 20.8 months, with a minimum of six months and a maximum of 50 months.

The mean length of time between the trauma and the surgery was 11.9 days, with a range from one to 34 days. The mean duration of rehabilitation with occupational therapy was 2.9 months (minimum of 0.2 months and maximum of 22 months), and the mean time taken to return to normal activities was four months. 
All the patients underwent a physical examination that consisted of measuring their range of motion using a goniometer and their grip strength with a dynamometer (Hydraulic Hand Dynamometer SH5001, Saehan Corporation). Three consecutive measurements were made in a standardized manner, with the patient standing, upper arm alongside the chest and forearm in neutral rotation. All the measurements were made on both the operated and the contralateral wrist.

The subjective clinical evaluation was made by applying the Disabilities of the Arm, Shoulder and Hand (DASH) questionnaire (Annex 1). This consists of 30 questions that can be self-administered, seeking information on the degree of difficulty in performing daily activities, pain symptoms, weakness, stiffness and paresthesia, while taking into consideration the patient's social and psychological impairments. Each item is scored from 1 to 5 and the total score can range from 0 (no dysfunction) to 100 (severe dysfunction). The total score is calculated by summing the scores from the 30 questions and then, from this sum, subtracting 30 and dividing by $1.2^{(24-26)}$.

A radiographic examination was performed on the fractured wrist and on the contralateral wrist, in anteroposterior and lateral views. The volar and radial tilt angles and radial length was noted. The preoperative radiograph was then assessed to classify the fracture in accordance with the system used by the AO Group ${ }^{(27)}$ (Figure 1 and Box 1).

The study project was approved by the hospital's Ethics Committee.

The operations were performed with the patient under anesthesia (either brachial plexus block or general anesthesia) and using a pneumatic tourniquet. The distal radius was approached using the palmar route described by Henry, thus enabling viewing of the fracture focus ${ }^{(28)}$.

The reduction procedure on the fracture was checked by means of radioscopy and provisional fixation was achieved using Kirschner wires. The plate was then located on the volar cortex and fixed to the bone by means of a screw at the opening of the slippage. Correct positioning of the implant was achieved under radioscopic monitoring. The other screws were placed in the subchondral bone, including locking screws. The monitoring was done using an image intensifier.

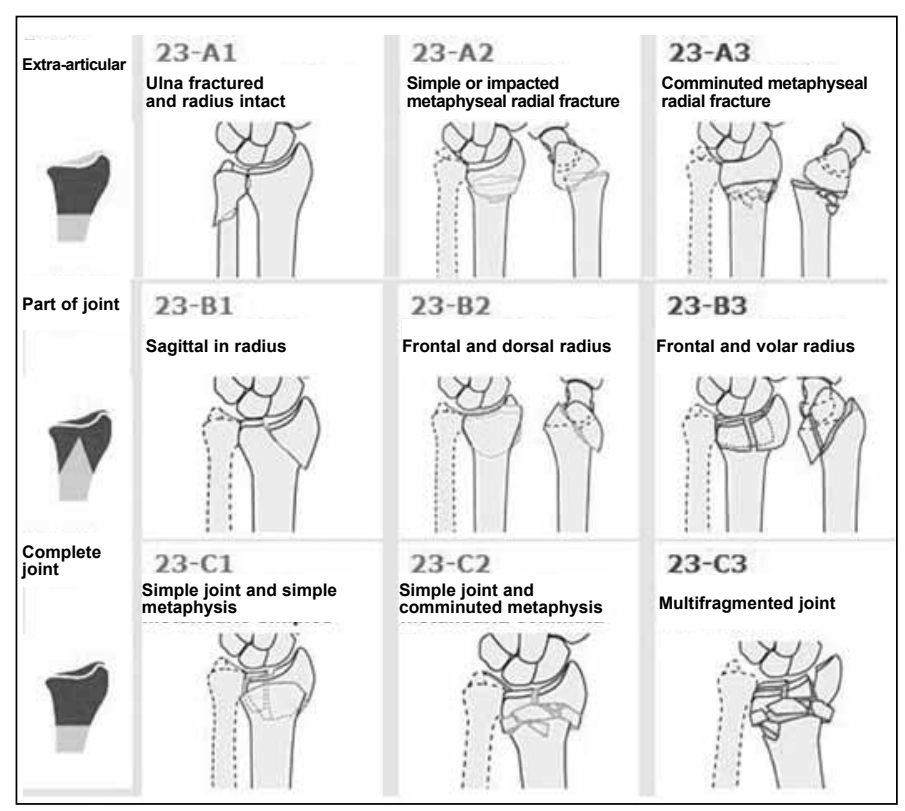

Figure 1- AO classification for fractures of the distal radius ${ }^{(27)}$.

Box 1- Distribution of fractures according to classification.

\begin{tabular}{|c|c|c|}
\hline AO & Quantity & $\%$ \\
\hline A1 & 0 & 0 \\
\hline A2 & 0 & 0 \\
\hline A3 & 4 & 6.2 \\
\hline B1 & 5 & 7.8 \\
\hline B2 & 2 & 3.1 \\
\hline B3 & 2 & 3.1 \\
\hline C1 & 23 & 35.9 \\
\hline C2 & 9 & 14.1 \\
\hline C3 & 19 & 29.7 \\
\hline Total & 64 & 100 \\
\hline
\end{tabular}

Bone grafts were not used in any of the cases. After the operation, the wrist was immobilized for 10 days using a forearm-to-palm splint, for analgesia. All the patients were advised to start making finger movements immediately. The suture was removed 15 days after the surgery.

Rehabilitation with occupational therapy was started after removing the splint, in order achieve gains in active and passive wrist movement.

Descriptive analysis consisting of means and standard deviations was performed on the data ${ }^{(29)}$. The quantitative variables measured in the two wrists were compared between the groups using the paired Student $\mathrm{t}$ test $\mathrm{t}^{(30)}$. To investigate associations with risk factors, the chi-square test was used, or Fisher's exact test in cases in which the frequency was less 
Annex 1- Rate how well you were able to do the following activities last week by circling the appropriate response below:

\begin{tabular}{|c|c|c|c|c|c|}
\hline & No difficulty & $\begin{array}{l}\text { A little } \\
\text { difficulty }\end{array}$ & $\begin{array}{l}\text { Moderate } \\
\text { difficulty }\end{array}$ & A lot of difficulty & $\begin{array}{c}\text { I wasn't able } \\
\text { to do it }\end{array}$ \\
\hline 1. Open a new glass jar, or one with a very tight lid & 1 & 2 & 3 & 4 & 5 \\
\hline 2. Write. & 1 & 2 & 3 & 4 & 5 \\
\hline 3. Turn a key & 1 & 2 & 3 & 4 & 5 \\
\hline 4. Prepare a meal & 1 & 2 & 3 & 4 & 5 \\
\hline 5. Open a heavy door & 1 & 2 & 3 & 4 & 5 \\
\hline 6. Put something on a shelf above head height & 1 & 2 & 3 & 4 & 5 \\
\hline 7. Do heavy domestic tasks (such as washing the floor) & 1 & 2 & 3 & 4 & 5 \\
\hline 8. Do gardening work & 1 & 2 & 3 & 4 & 5 \\
\hline 9. Make your bed & 1 & 2 & 3 & 4 & 5 \\
\hline 10. Carry a bag or a small case & 1 & 2 & 3 & 4 & 5 \\
\hline 11. Carry a heavy object (more than $5 \mathrm{~kg}$ ). & 1 & 2 & 3 & 4 & 5 \\
\hline 12. Change a light bulb above head height & 1 & 2 & 3 & 4 & 5 \\
\hline 13. Wash or dry your hair & 1 & 2 & 3 & 4 & 5 \\
\hline 14. Wash your back & 1 & 2 & 3 & 4 & 5 \\
\hline 15. Put on a closed blouse & 1 & 2 & 3 & 4 & 5 \\
\hline 16. Use a knife to cut food & 1 & 2 & 3 & 4 & 5 \\
\hline $\begin{array}{l}\text { 17. Recreational activities that require little effort (such as } \\
\text { playing cards or knitting) }\end{array}$ & 1 & 2 & 3 & 4 & 5 \\
\hline $\begin{array}{l}\text { 18. Recreational activities that require strength or impact in } \\
\text { the arms, shoulders or hands (such as playing volleyball or } \\
\text { hammering) }\end{array}$ & 1 & 2 & 3 & 4 & 5 \\
\hline $\begin{array}{l}\text { 19. Recreational activities in which you move your arm freely } \\
\text { (such as fishing or playing shuttlecock) }\end{array}$ & 1 & 2 & 3 & 4 & 5 \\
\hline $\begin{array}{l}\text { 20. Transport from one place to another (going from one place } \\
\text { to another) }\end{array}$ & 1 & 2 & 3 & 4 & 5 \\
\hline \multirow[t]{2}{*}{ 21. Sexual activities } & 1 & 2 & 3 & 4 & 5 \\
\hline & $\begin{array}{l}\text { It didn't affect } \\
\text { them }\end{array}$ & $\begin{array}{l}\text { It affected them } \\
\text { slightly }\end{array}$ & $\begin{array}{l}\text { It affected them } \\
\text { moderately }\end{array}$ & $\begin{array}{l}\text { It affected them } \\
\text { a lot }\end{array}$ & $\begin{array}{l}\text { It affected them } \\
\text { enormously }\end{array}$ \\
\hline \multirow[t]{2}{*}{$\begin{array}{l}\text { 22. Last week, to what extent did your arm, shoulder or hand } \\
\text { problem affect your normal activities with your family, friends, } \\
\text { neighbors or colleagues? }\end{array}$} & 1 & 2 & 3 & 4 & 5 \\
\hline & $\begin{array}{l}\text { It didn't limit } \\
\text { them }\end{array}$ & $\begin{array}{l}\text { It limited them } \\
\text { slightly }\end{array}$ & $\begin{array}{l}\text { It limited them } \\
\text { moderately }\end{array}$ & $\begin{array}{l}\text { It limited them } \\
\text { a lot }\end{array}$ & $\begin{array}{l}\text { I wasn't able } \\
\text { to do them }\end{array}$ \\
\hline $\begin{array}{l}\text { 23. Last week, were your work or normal daily activities limited } \\
\text { because of your arm, shoulder or hand problem? }\end{array}$ & 1 & 2 & 3 & 4 & 5 \\
\hline $\begin{array}{l}\text { Rate how severe the following symptoms were last } \\
\text { week }\end{array}$ & None & A little & Moderate & A lot & Extreme \\
\hline 24. Pain in your arm, shoulder or hand & 1 & 2 & 3 & 4 & 5 \\
\hline $\begin{array}{l}\text { 25. Pain in your arm, shoulder or hand when you did } \\
\text { specific activities }\end{array}$ & 1 & 2 & 3 & 4 & 5 \\
\hline $\begin{array}{l}\text { 26. Discomfort in the skin of your arm, shoulder or } \\
\text { hand (prickling) }\end{array}$ & 1 & 2 & 3 & 4 & 5 \\
\hline 27. Weakness in your arm, shoulder or hand & 1 & 2 & 3 & 4 & 5 \\
\hline \multirow[t]{2}{*}{ 28. Difficulty in moving your arm, shoulder or hand } & 1 & 2 & 3 & 4 & 5 \\
\hline & No difficulty & $\begin{array}{l}\text { A little } \\
\text { difficulty }\end{array}$ & $\begin{array}{l}\text { Moderate } \\
\text { difficulty }\end{array}$ & A lot of difficulty & $\begin{array}{c}\text { So difficult that } \\
\text { I wasn't able to } \\
\text { sleep }\end{array}$ \\
\hline \multirow[t]{2}{*}{$\begin{array}{l}\text { 29. Last week, did you have any difficulty in sleeping } \\
\text { because of pain in your arm, shoulder or hand? }\end{array}$} & 1 & 2 & 3 & 4 & 5 \\
\hline & $\begin{array}{c}\text { Totally } \\
\text { disagree }\end{array}$ & Disagree & $\begin{array}{c}\text { Neither agree nor } \\
\text { disagree }\end{array}$ & Agree & Totally agree \\
\hline $\begin{array}{l}\text { 30. I feel less capable, less confident and less useful } \\
\text { because of my arm, shoulder or hand problem }\end{array}$ & 1 & 2 & 3 & 4 & 5 \\
\hline
\end{tabular}


than five individuals ${ }^{(31)}$. For inferential analyses, the significance level was taken to be $5 \%(\alpha=0.05)$.

\section{RESULTS}

Among the 64 patients evaluated in this study, eight presented complications. One patient remained off work because of sympathetic reflex dystrophy (one case). Among the complications and complaints evaluated, the ones that required a new surgical intervention were: four cases of intra-articular screws (Figure 2, a and b), two cases of carpal tunnel syndrome and one case of injury of the long extensor tendon of the thumb. All of these complications appeared during the patients' outpatient follow-up, in the late postoperative period.

No cases of infections were observed, and the fractures consolidated in all cases. In the physical examinations on the patients, the mean mobility observed in the affected wrist and the percentages in relation to the unaffected limb were: $51.83^{\circ}$ and $82.8 \%$ for extension; $47.23^{\circ}$ and $75.4 \%$ for flexion; $82.52^{\circ}$ and $95.8 \%$ for supination; $24.92^{\circ}$ and $87.4 \%$ for radial
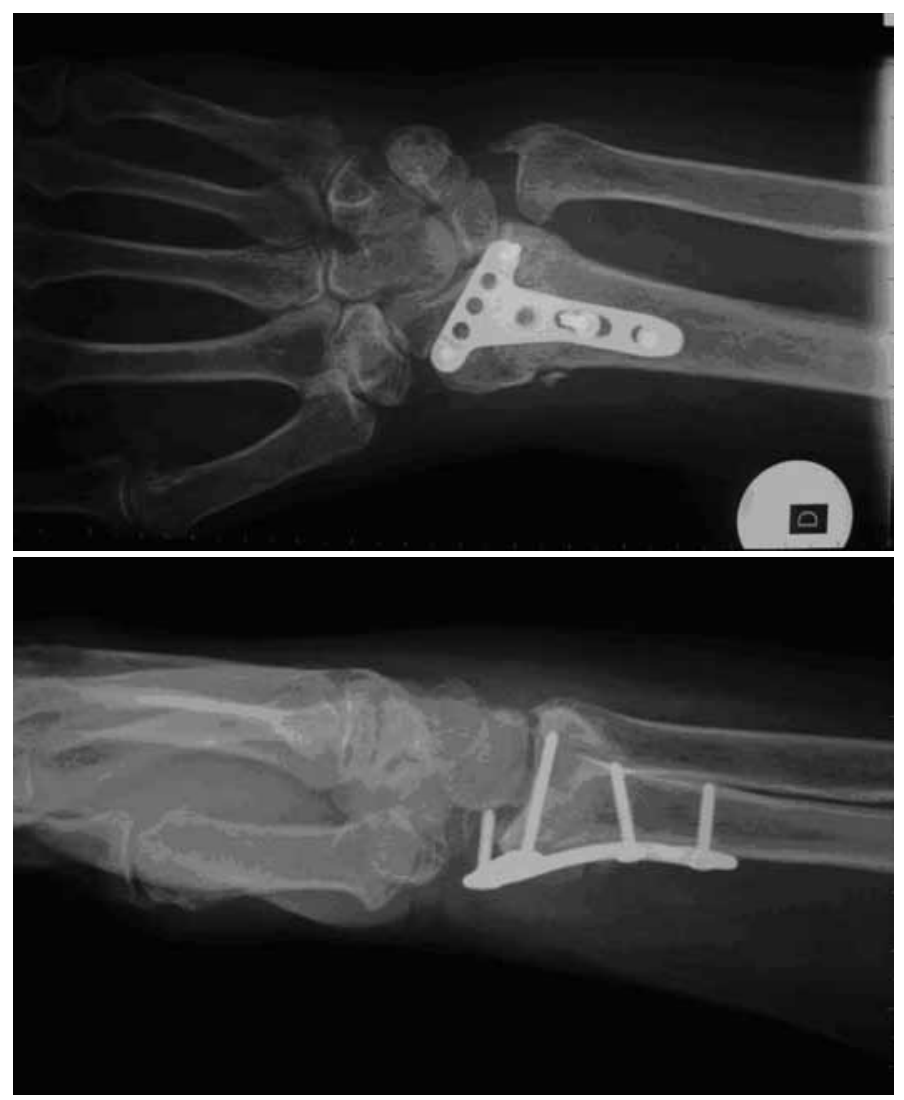

Figura 2 - a) Radiografia em anteroposterior do punho com placa volar mostrando parafuso intra-articular; b) Radiografia oblíqua da mesma paciente. deviation; and $33.25^{\circ}$ and $83.3 \%$ for ulnar deviation (Figure 3). The mean grip strength measured in kilogram-force (kgf) was 21.75 , i.e. $85.8 \%$ of the grip strength of the unaffected side (Figure 4). The values for the fractured and non-fractured limbs were different, and this difference was statistically significant.

To subjectively assess the patients' functional abilities, the DASH questionnaire was use, and the mean value found was 15.99, with a range from 0 to 61.7 .

On the radiographs, the means of the angular values on the affected side and the percentages in relation to the non-fractured side were: $17.47^{\circ}$ and $84.0 \%$ for radial tilt; $8.23 \mathrm{~mm}$ and $85.4 \%$ for radial length; and

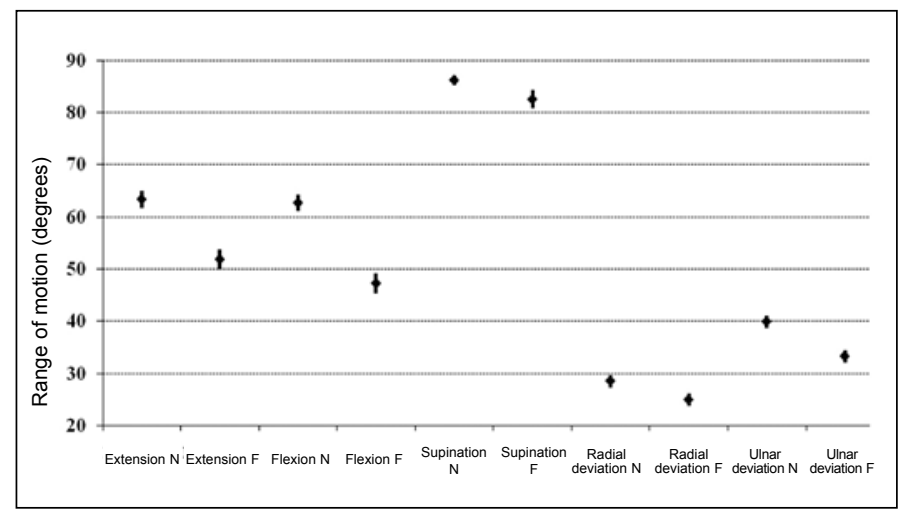

Figure 3 - Measurements of mobility in degrees between the normal side $(N)$ and fractured side $(F)$, expressed as the mean and standard error.

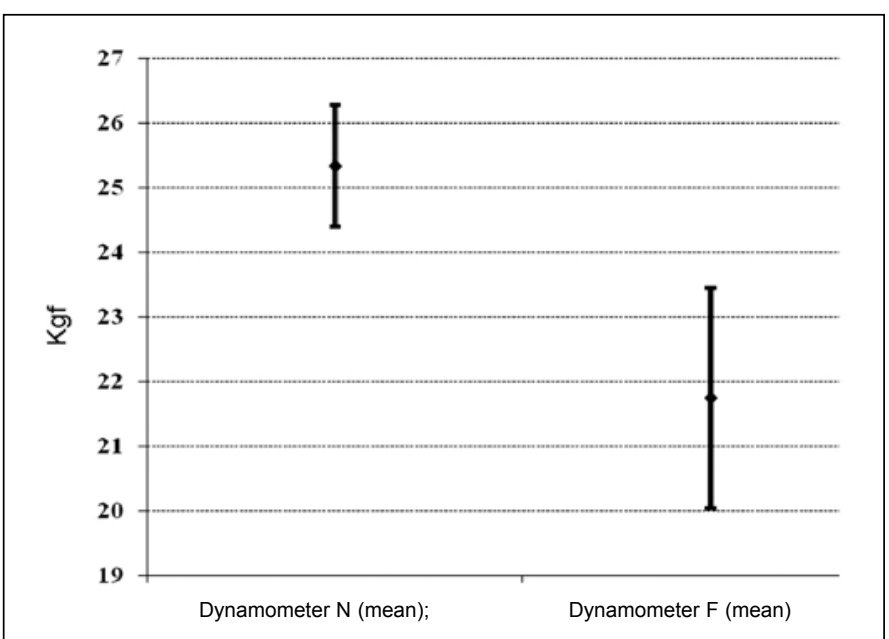

Figure 4 - Force measurements from dynamometer, between normal and fractures sides, expressed as the mean and standard error.

$10.27^{\circ}$ and $86.8 \%$ for volar deviation of the radius. All the measured differences between the operated and non-operated sides were statistically significant.

From correlating the measurements with each other, some significant relationships were found. There was a relationship between the difference in 
extension between the non-fractured and fractured limbs $(\mathrm{N}-\mathrm{F})$ and the difference in dynamometer measurements between the non-fractured and fractured limbs. In other words, the greater the loss of extension was, the greater the loss of palmar grip strength was (Figure 5).

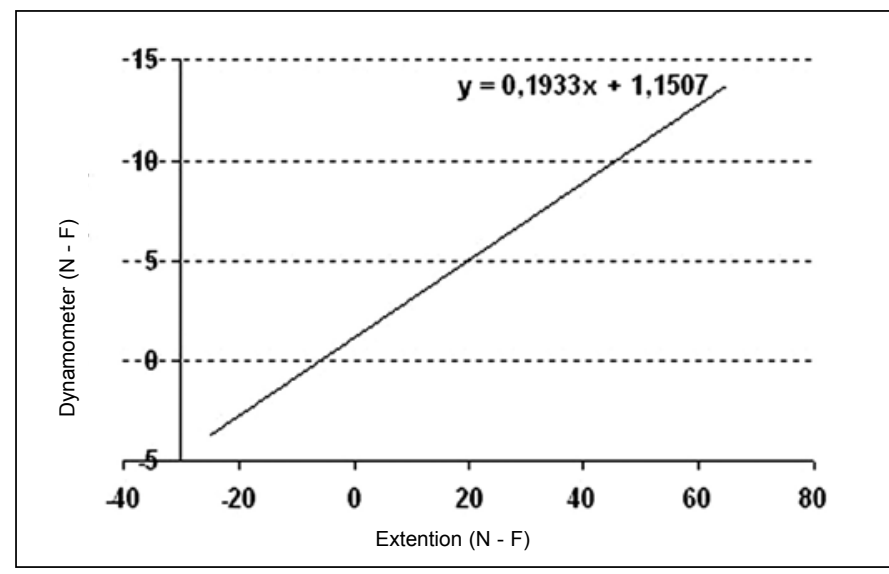

Figure 5 - Relationship between the dynamometer and extension measurements relating to the difference between the normal and fractured sides.

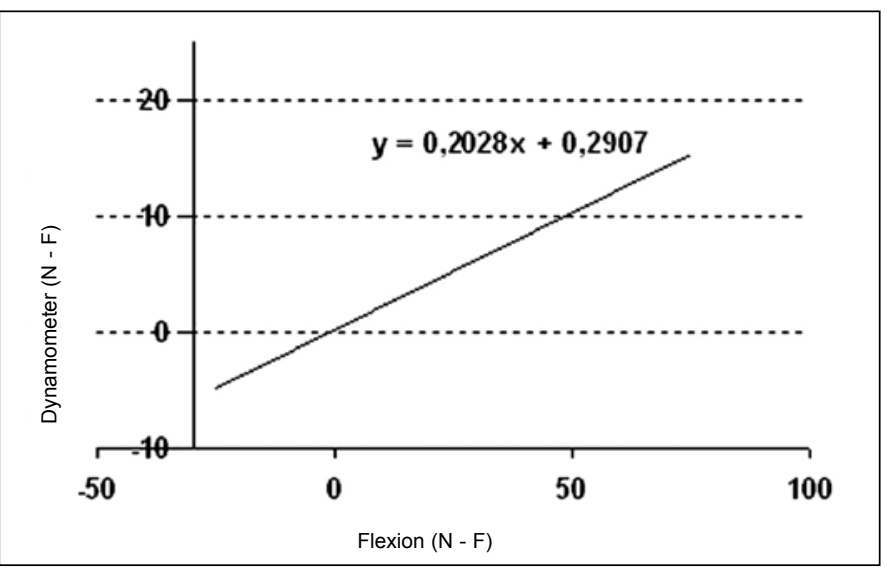

Figure 6 - Relationship between the dynamometer and flexion measurements relating to the difference between the normal and fractured sides.

A similar relationship was found between flexion and the dynamometer measurements (Figure 6).

There was also a relationship between the difference in extension of the fractured and non-fractured limbs and the difference in radial length of the fractured and non-fractured limbs (Figure 7). In addition to this relationship, the extension also correlated with the DASH score (Figure 8).

The change in dynamometer measurements between the fractured and non-fractured sides also correlated with the DASH score (Figure 9). No association was found between the radiographic measurements and DASH.
There was no significant difference regarding the various measurements of the physical examination, radiographic examination or subjective assessment, or regarding the type of fracture (AO classification).

There was no difference between the fractured

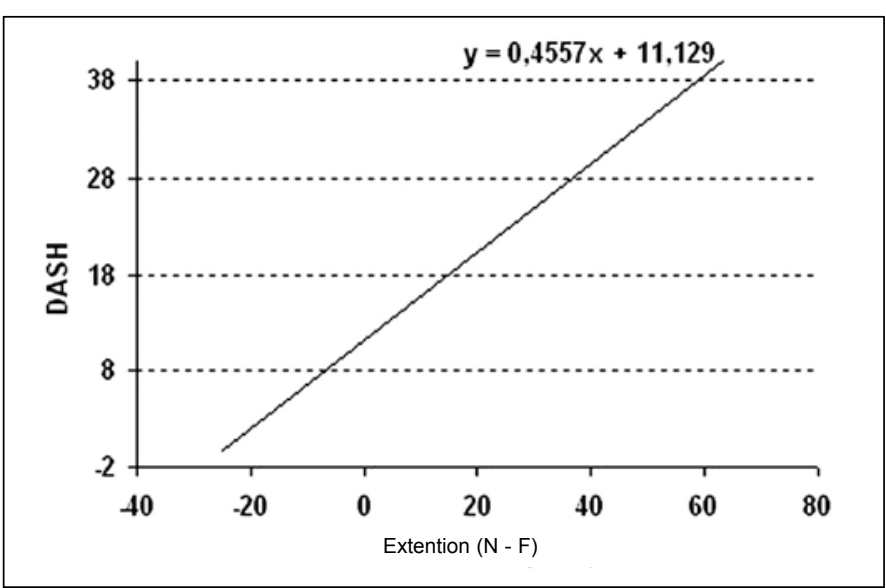

Figure 7 - Relationship between the extension and radial length measurements relating to the difference between the normal and fractured sides.

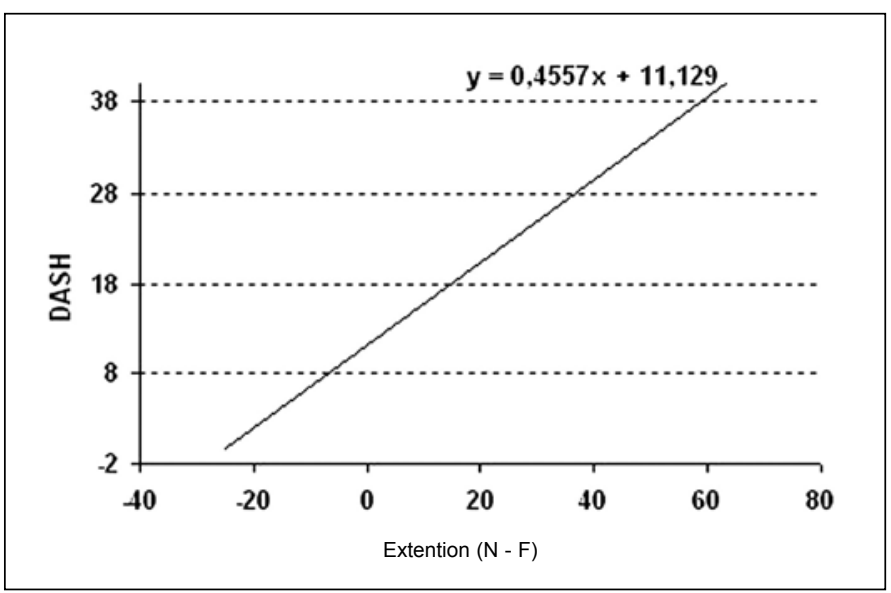

Figure 8 - Relationship between extension (difference in normal and fractured sides) and the DASH score.

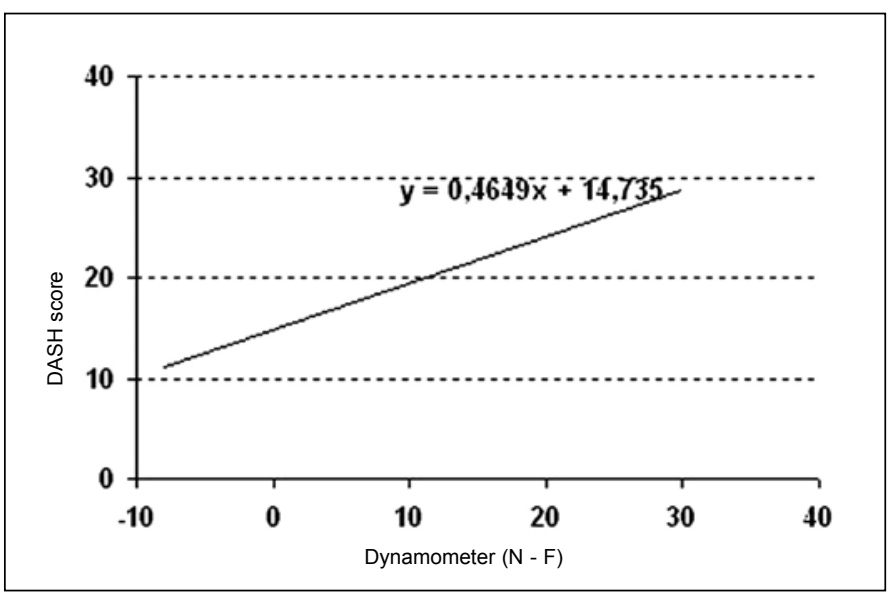

Figure 9 - Relationship between dynamometer measurements (difference in normal and fractured sides) and the DASH score. 
side and the patient's dominant side, or between the various variables and whether the fractured limb was the dominant one or not.

In relation to the patients' ages in this sample, it was observed that there was bimodal distribution of fractures, with concentrations among elderly women and non-elderly adult men (Figure 10).

It was also observed that there was greater loss of extension and flexion (greater difference in $\mathrm{N}-$ F) among the female patients than among the male patients. No other significant findings were observed in relation to the patients' sex.

From grouping the patients as elderly ( $>60$ years) and non-elderly adults ( $<60$ years), no statistical differences were observed between the various radiographic measurements and the physical examination. However, a notable significant relationship was observed between the two groups and the DASH score (Figure 11).

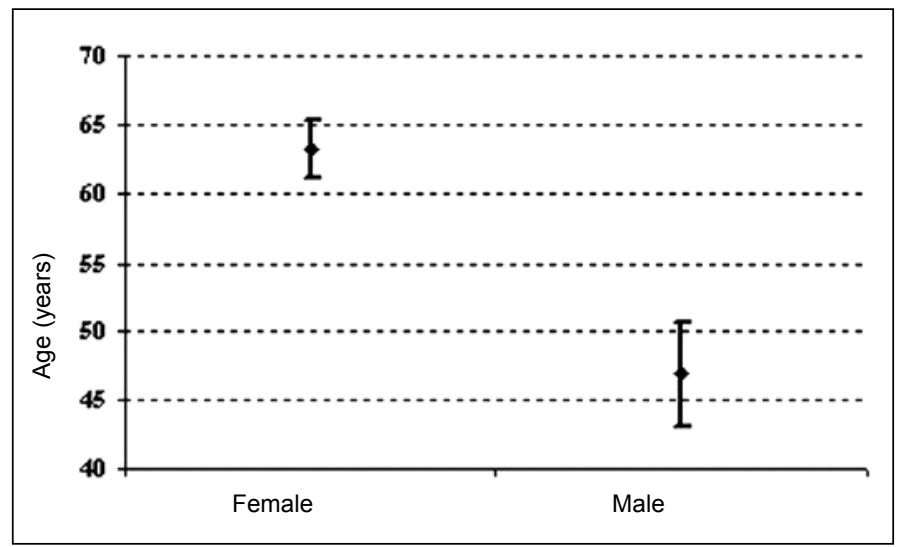

Figure 10 - Means and standard deviations of age, according to patients' sex.

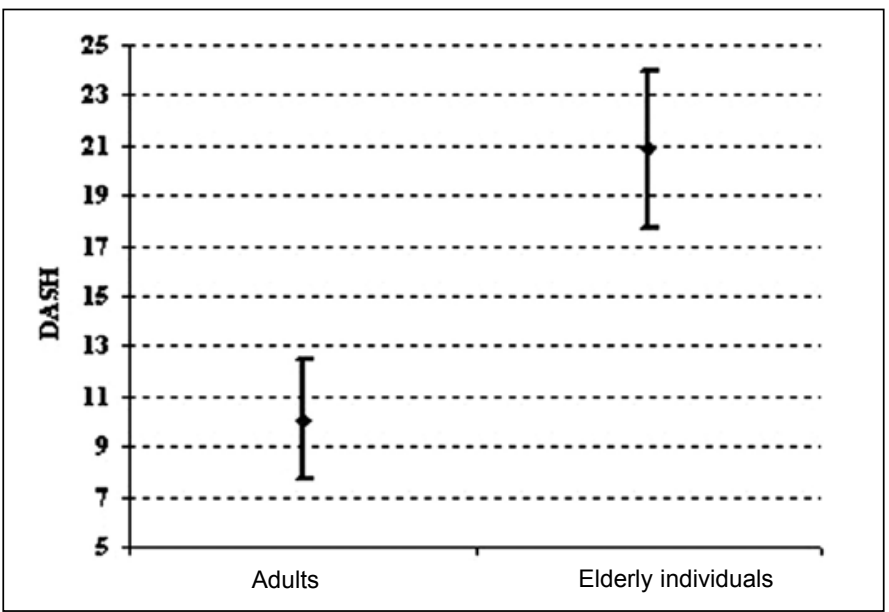

Figure 11 - Means and standard errors of DASH scores, according to age category (elderly individuals and non-elderly adults).

\section{DISCUSSION}

Locked volar plates are now greatly used as a treatment method for unstable distal radius fractures. They present a biomechanical advantage and a lower risk of tendon complications than shown by dorsal plates $^{(14)}$. The results from using this type of plate have shown varying incidence of complications (from three to $27 \%$ ). Loss of range of motion and grip strength were also observed, but with few functional repercussions $^{(32-35)}$.

Kamano et $a l^{(33)}$ evaluated 40 patients with dorsally deviated fractures of the distal radius who had been treated using volar plates. Bone grafts were required in the cases of four patients. Among the operated fractures, 34 were extra-articular. They reported one case of sympathetic reflex dystrophy and one of infection of the operative wound, as complications.

Drobetz and Kutscha-Lissberg ${ }^{(34)}$ published the results from 50 patients with fractures of the distal radius who had been treated using a fixed-angle volar plate. They used bone grafts in C2 and C3 fractures. They reported that three patients presented sympathetic reflex dystrophy, one had carpal tunnel syndrome, one had a tear in the long extensor muscle tendon of the thumb and six had tears of the long flexor tendon of the thumb; and that there was one case of failure of the synthesis material. Rozental and Blazar $^{(35)}$ showed the fixation results from 41 patients and reported that tenosynovitis of flexor tendons and skewed consolidation were the main complications.

Our study demonstrated complications that were comparable with the results found in the literature (Table 1). The incidence of intra-articular screws may have been related to the type of plate used. The distal fixed-angle screws of this plate are at an angle of 95 degrees in order to facilitate juxtacortical positioning, which provides greater stability for the fracture. However, in intra-articular fractures, in which the screws need to be inserted more distally, these screws may penetrate the radiocarpal joint ${ }^{(2,33)}$.

Orbay and Fernande $z^{(13)}$ evaluated 29 patients with fractures treated using a fixed-angle volar plate. After one year of follow-up, they analyzed the losses of grip strength. The strength was $79 \%$ in relation to the contralateral side (Table 2).

Arora et $a l^{(2)}$ compared the functional results from 53 patients over the age of 70 years who were treated using a fixed-angle volar plate with the results 
from 61 patients who were treated using a closed procedure. There were no objective or subjective functional differences between the groups in the final result, and this led them to question the use of surgical treatment for elderly individuals. We found a notable relationship between patient age and DASH score. Our patients aged over 60 years reported more

Table 1 - Comparison of complications found in other studies with those in the present study.

\begin{tabular}{|c|c|c|c|c|c|}
\hline & $\begin{array}{c}\text { Drobetz/ } \\
\text { Kutscha- } \\
\text { Lissberg } \\
2003\end{array}$ & $\begin{array}{c}\text { Kamano } \\
\text { et al. } \\
2005\end{array}$ & $\begin{array}{c}\text { Rozental/ } \\
\text { Blazar } \\
2006\end{array}$ & Arora et & $\begin{array}{l}\text { Present } \\
\text { study } \\
2010\end{array}$ \\
\hline Patients (n) & 50 & 40 & 41 & 114 & 64 \\
\hline $\begin{array}{l}\text { Tear in the long } \\
\text { flexor tendon of } \\
\text { the thumb }\end{array}$ & $6(12 \%)$ & $\mathrm{Np}$ & $\mathrm{Np}$ & $2(2 \%)$ & 0 \\
\hline $\begin{array}{l}\text { Tear in the long } \\
\text { extensor tendon of } \\
\text { the thumb }\end{array}$ & $1(2 \%)$ & $\mathrm{Np}$ & $\mathrm{Np}$ & $2(2 \%)$ & $1(1.5 \%)$ \\
\hline $\begin{array}{l}\text { Tenosynovitis of } \\
\text { the flexor tendons }\end{array}$ & $\mathrm{Np}$ & $\mathrm{Np}$ & $2(5 \%)$ & $9(8 \%)$ & 0 \\
\hline $\begin{array}{l}\text { Tenosynovitis } \\
\text { of the extensor } \\
\text { tendons }\end{array}$ & $\mathrm{Np}$ & $\mathrm{Np}$ & $1(2 \%)$ & $4(4 \%)$ & 0 \\
\hline $\begin{array}{l}\text { Carpal tunnel } \\
\text { syndrome }\end{array}$ & $1(2 \%)$ & $\mathrm{Np}$ & $\mathrm{Np}$ & $3(3 \%)$ & $2(3 \%)$ \\
\hline $\begin{array}{c}\text { Delayed } \\
\text { consolidation/ } \\
\text { pseudarthrosis }\end{array}$ & $\mathrm{Np}$ & $\mathrm{Np}$ & $\mathrm{Np}$ & $3(3 \%)$ & 0 \\
\hline $\begin{array}{l}\text { Sympathetic } \\
\text { reflex dystrophy }\end{array}$ & $3(6 \%)$ & $1(3 \%)$ & $\mathrm{Np}$ & $5(4 \%)$ & $1(1.5 \%)$ \\
\hline $\begin{array}{c}\text { Failure of } \\
\text { synthesis material }\end{array}$ & $1(2 \%)$ & $\mathrm{Np}$ & $\mathrm{Np}$ & $2(2 \%)$ & 0 \\
\hline $\begin{array}{c}\text { Skewed } \\
\text { consolidation }\end{array}$ & $\mathrm{Np}$ & $\mathrm{Np}$ & $3(7 \%)$ & $\mathrm{Np}$ & 0 \\
\hline $\begin{array}{l}\text { Intra-articular } \\
\text { screw }\end{array}$ & $\mathrm{Np}$ & $\mathrm{Np}$ & $\mathrm{Np}$ & $1(0.9 \%)$ & $4(6.2 \%)$ \\
\hline Total & $13(26 \%)$ & $1(3 \%)$ & $6(14 \%)$ & $31(27 \%)$ & $8(12.5 \%)$ \\
\hline
\end{tabular}

Percentages between parentheses

Np: not published.

Table 2 - Comparison of grip strength with other studies.

\begin{tabular}{c|c|c|c|c}
\hline & $\begin{array}{c}\text { Orbay e } \\
\text { Fernandez } \\
\mathbf{2 0 0 2}\end{array}$ & $\begin{array}{c}\text { Arora } \\
\text { et al. } \\
\mathbf{2 0 0 7}\end{array}$ & $\begin{array}{c}\text { Arora et al. } \\
\mathbf{2 0 0 9}\end{array}$ & $\begin{array}{c}\text { Present } \\
\text { study 2010 }\end{array}$ \\
\hline $\begin{array}{c}\text { Grip strength } \\
\text { \% of unaffected } \\
\text { side) }\end{array}$ & 79 & 70 & 75.3 & 85.8 \\
\hline
\end{tabular}

functional difficulties (higher DASH), independent of the radiographic indexes or type of fracture.

In our study, we observed that extension, flexion and grip strength losses were associated with worse DASH results. Karnezis and Fragkiadakis ${ }^{(36)}$ attributed the worsening of the patients' subjective functional results mainly to grip strength and extension losses among 25 patients treated with Kirschner wires.

Like Karnezis et $a l^{(37)}$, we did not observe any correlation between the AO classification of the fracture and the results from the functional questionnaire applied.

The relationship between the radiographic indexes obtained after the operation and subjective questionnaires evaluating patients' functional limitations is small, independent of the type of treatment used ${ }^{(37,38)}$. Barton et $a l^{(17)}$ did not find any association between radial shortening or radial tilt and the subjective PRWE questionnaire score. There was no relationship between loss of volar angle and functional questionnaires, according to Anzarut et $a l^{(18)}$. Our results resembled these, in that none of the radiographic measurements significantly altered the DASH score.

Trumble et $a l^{(39)}$ analyzed distal radial fractures treated using intrafocal Kirschner wires and observed that the most important radiographic measurement for determining that the functional results were good was maintenance of radial length. Tang et $a l^{(20)}$ conducted biomechanical studies on cadavers after experimental radial shortening and came to the conclusion that loss of only $2.5 \mathrm{~mm}$ in radial length was enough to cause significant changes in the moment of force of the extensor and flexor tendons. In the present study, this was the only radiographic measurement that influenced patients' range of motion. In losing radial length in relation to the contralateral side, patients evolved with significant losses of extension and grip strength $(\mathrm{p}<0.05)$.

The limitations of this study that should be taken into consideration are that its design was retrospective; patient evaluations were performed only once during the postoperative period; there was no investigation of fractures of the ulnar styloid process or of degenerative signs in the radiocarpal joint. 


\section{CONCLUSIONS}

The objective and subjective clinical results from surgical treatment of fractures of the distal radius have little correlation with the radiographic indexes. Radial shortening influenced the range of motion and grip strength, and was the only radiographic value to change the patients' objective clinical results. The subjective results (DASH scores) were only influenced by age, grip strength and extension range, without any relationship with radiographic measurements.

Use of volar plates is a treatment method with a low complication rate. However, caution is needed in indicating this for elderly patients, and the patient's activity level and the risks and benefits need to be taken into consideration.

\section{REFERENCES}

1. Reis FB, Faloppa F, Saone RP, Boni JR, Corvelo MC. Fraturas do terço dista do rádio: classificação e tratamento. Rev Bras Ortop. 1994;29 (5):326-330.

2. Arora R, Gabl M, Gschwentner M, Deml C, Krappinger D, Lutz M. A comparative study of clinical and radiologic outcomes of unstable colles type distal radius fractures in patients older than 70 years: nonoperative treatment versus volar locking plating. J Orthop Trauma. 2009;23(4):237-42

3. O'Neill TW, Cooper C, Finn JD, Lunt M, Purdie D, Reid DM, et al. Incidence of distal forearm fracture in British men and women. Osteoporos Int 2001;12(7):555-8.

4. McQueen MM, Hajducka C, Court-Brown CM. Redisplaced unstable fractures of the distal radius: a prospective randomised comparison of four methods of treatment. J Bone Joint Surg Br. 1996;78(3):404-9.

5. Liporace FA, Adams MR, Capo JT, Koval KJ. Distal radius fractures. J Orthop Trauma. 2009;23(10):739-48

6. McCall TA, Conrad B, Badman B, Wright T. Volar versus dorsal fixed-angle fixation of dorsally unstable extra-articular distal radius fractures: a biomechanic study. J Hand Surg Am. 2007;32(6):806-12.

7. Kapandji A. [Internal fixation by double intrafocal plate. Functional treatment of non articular fractures of the lower end of the radius (author's transl)]. Ann Chir. 1976;30(11-12):903-8.

8. Ring D, Jupiter JB, Brennwald J, Büchler U, Hastings $H$ 2nd. Prospective multicenter trial of a plate for dorsal fixation of distal radius fractures. J Hand Surg Am. 1997;22(5):777-84.

9. Osada D, Viegas SF, Shah MA, Morris RP, Patterson RM. Comparison of different distal radius dorsal and volar fracture fixation plates: a biomechanical study. J Hand Surg Am. 2003;28(1):94-104.

10. Wong KK, Chan KW, Kwok TK, Mak KH. Volar fixation of dorsally displaced distal radial fracture using locking compression plate. J Orthop Surg (Hong Kong). 2005;13(2):153-7.

11. Lorich DG, Gardner MJ. Placas. In: Rüedi TP, Buckley RE, Moran CG Principios $\mathrm{AO}$ do tratamento de fraturas. Tradução de Jacques Vissoky. 2a ed. Porto Alegre: Artmed; 2009.

12. Arora R, Lutz M, Hennerbichler A, Krappinger D, Espen D, Gabl M. Complications following internal fixation of unstable distal radius fracture with a palmar locking-plate. J Orthop Trauma. 2007;21(5):316-22.

13. Orbay JL, Fernandez DL. Volar fixation for dorsally displaced fractures of the distal radius: a preliminary report. J Hand Surg Am. 2002;27(2):205-15.

14. Jupiter JB, Marent-Huber M, LCP Study Group. Operative management of distal radial fractures with 2.4-millimeter locking plates. A multicenter prospective case series. J Bone Joint Surg Am. 2009;91(1):55-65.

15. Ruschel PH, Oliveira RK, Pignataro MB, Folberg CR, Praetzel RP, Borges CS. Emprego de placa de ângulo fixo no tratamento de fraturas com deslocamento dorsal da extremidade distal do rádio. Rev Bras Ortop.2007;42(1/2):17-23.

16. Leung F, Zhu L, Ho H, Lu WW, Chow SP. Palmar plate fixation of AO type C2 fracture of distal radius using a locking compression plate - a biomechanical study in a cadaveric model. J Hand Surg Br. 2003;28(3):263-6.

17. Barton T, Chambers C, Bannister G. A comparison between subjective outcome score and moderate radial shortening following a fractured distal radius in patients of mean age 69 years. J Hand Surg Eur Vol. 2007;32(2):165-9.

18. Anzarut A, Johnson JA, Rowe BH, Lambert RG, Blitz S, Majumdar SR. Radiologic and patient-reported functional outcomes in an elderly cohort with conservatively treated distal radius fractures. J Hand Surg Am. 2004;29(6):1121-7.
19. Tsukazaki T, Takagi K, Iwasaki K. Poor correlation between functional results and radiographic findings in Colles' fracture. J Hand Surg Br. 1993;18(5):588-91.

20. Tang JB, Ryu J, Kish V, Wearden S. Effect of radial shortening on muscle length and moment arms of the wrist flexors and extensors. J Orthop Res. 1997;15(3):324-30

21. Albertoni WM, De Paula EJL, Toledo LF MQ, Giostri G, De Freitas A. Fraturas instáveis da extremidade distal do rádio: estudo mulicêntrico. Rev Bras Ortop. 2002;37(10):436-44.

22. Cooney WP 3rd, Dobyns JH, Linscheid RL. Complications of Colles' fractures. J Bone Joint Surg Am. 1980;62(4):613-9.

23. Lafontaine $M$, Hardy $D$, Delince $P$. Stability assessment of distal radius fractures. Injury. 1989;20(4):208-10.

24. Hudak PL, Amadio PC, Bombardier C. Development of an upper extremity outcome measure: the DASH (disabilities of the arm, shoulder and hand) [corrected]. The Upper Extremity Collaborative Group (UECG). Am J Ind Med. 1996;29(6):602-8.

25. Orfale AG. Tradução e validação do Disabilities of the Arm, Shoulder and Hand(DASH) para a língua portuguesa [dissertação]. São Paulo: Universidade Federal de São Paulo, Escola Paulista de Medicina; 2003.

26. Amadio PC. Outcomes assessment in hand surgery. What's new? Clin Plast Surg. 1997;24(1):191-4.

27. Muller ME, Nazarian S, Koch P, Schatzker J. The comprehensive classification of fractures of long bones. New York: Springer-Verlag; 1990.

28. Henry AK. Extensile exposure. 2nd ed. Baltimore: Williams \& Wilkins; 1970.

29. Vieira S. Introdução à bioestatística. Rio de Janeiro: Campus; 1998.

30. Magalhães MN, Lima ACP. Noções de probabilidade e estatística. São Paulo: IME-USP; 2000.

31. Neter J, Kutner MH, Nachtsheim CJ and LI W. Applied Linear Statistical Models. Boston: McGraw-Hill; 2004.

32. Reis FB, Machado JKS. Fraturas da extremidade distal do rádio e da ulna - tratamento cruento. In: Pardini A, Freitas A. Traumatismos da Mão. Rio de Janeiro: Medbook; 2008. p.438-45.

33. Kamano M, Koshimune M, Toyama M, Kazuki K. Palmar plating system for Colles' fractures--a preliminary report. J Hand Surg Am. 2005;30(4):750-5.

34. Drobetz $\mathrm{H}$, Kutscha-Lissberg $\mathrm{E}$. Osteosynthesis of distal radial fractures with a volar locking screw plate system. Int Orthop. 2003;27(1):1-6

35. Rozental TD, Blazar PE. Functional outcome and complications after volar plating for dorsally displaced, unstable fractures of the distal radius. J Hand Surg Am. 2006;31(3):359-65.

36. Karnezis IA, Fragkiadakis EG. Association between objective clinical variables and patient-rated disability of the wrist. J Bone Joint Surg Br. 2002;84(7):967-70.

37. Karnezis IA, Panagiotopoulos E, Tyllianakis M, Megas P, Lambiris E. Correlation between radiological parameters and patient-rated wrist dysfunction following fractures of the distal radius. Injury. 2005;36(12):1435-9.

38. Altissimi M, Antenucci R, Fiacca C, Mancini GB. Long-term results of conservative treatment of fractures of the distal radius. Clin Orthop Relat Res. 1986;(206):202-10

39. Trumble TE, Wagner W, Hanel DP, Vedder NB, Gilbert M. Intrafocal (Kapandji) pinning of distal radius fractures with and without external fixation. J Hand Surg Am. 1998;23(3):381-94. 